\title{
PERFIL DE CRIMINOSOS SEXUAIS
}

\author{
Vilene Eulálio de Magalhães ${ }^{1}$ \\ Maria Luiza Macedo de Araújo²
}

\section{Resumo}

Este trabalho avaliou a história de vida, a personalidade e a situação juridica de agressores sexuais que cumprem pena na penitenciária Nelson Hungria, em Contagem, Minas Gerais.

Para alcançar esses objetivos, foram investigadas: a ocorrência de violência doméstica na infância, as condições atuais quanto à sexualidade, a presença de disfunções sexuais, a satisfação sexual através de atos socialmente condenados, o uso de álcool e/ou drogas ilícitas, as relações de poder, estereótipos de gênero e as preferências sexuais destes sujeitos. Após uma revisão histórica da violência sexual, foram discutidas suas bases biológicas, fisiológicas e genéticas, além dos fatores psicossociais e psicopatológicos que podem estar relacionados com a agressão sexual. 0 referencial teórico aborda, igualmente, a legislação brasileira vigente sobre os crimes sexuais.

Na metodologia da pesquisa, foram usados diversos instrumentos: teste psicométrico (Inventário Multifásico Minesota de Personalidade- MMPI),

\footnotetext{
'Psicóloga, Mestre em Sexologia pela UGF/RJ - E-mail: vileneeulalio@aol.com

${ }^{2}$ Psicóloga, Mestre em Psicologia, Doutora em Filosofia e professora de mestrado em Sexologia da UGF/RJ - E-mail: luaraujo.rlk@terra.com.br
} 
dados de arquivo dos detentos e entrevista semi-dirigida. A amostra constou de 80 sujeitos, cuja participação foi voluntária.

Os resultados apontam uma presença significativa de psicopatologias; de práticas criminais; de violência doméstica na infância; de crenças, valores e comportamentos estereotipados; de associação uso de álcool e drogas ilícitas aos atos delituosos. Os agressores sexuais negam a preferência por atos sexuais socialmente condenados, mas reforçam a idéia da parceira ideal, sustentada em estereótipos de gênero.

Conclui-se que a necessidade de capacitação de profissionais voltados para esta questão é imprescindivel, tanto no tratamento, como na prevenção das violências sexuais, bem como a criação de métodos educacionais e psicoterápicos voltados para valores, tais como: liberdade sexual que respeite o outro em todos os aspectos; responsabilidade com a própria sexualidade, conscientização dos direitos e deveres de cidadão, amor pela vida e pelo próximo, dentre outros, que estão praticamente ausentes entre os criminosos condenados que fizeram parte do presente trabalho. 